\title{
Effect of HPMC Concentration Variation as Gelling Agent on Physical Stability of Formulation Gel Ethanol Extract Bundung Plants (Actinuscirpus Grossus)
}

\author{
Noval $^{1}$, Rosyifa $^{2}$, Annisa $^{3}$ \\ \{novalhalim10@gmail.com ${ }^{1}$, rosyifaj02@gmail.com ${ }^{2}$, annisaica1230@ gmail.com ${ }^{3}$ \} \\ Pharmacy Department, Health Faculty, Sari Mulia University, Banjarmasin 1,2,3
}

\begin{abstract}
Bundung Plant is a efficacious as an antimicrobial. In maximizing its use gel formulation are made from ethanol extract of Bundung Plant. The purpose of this study was to know variations in concentrations HPMC as gel agents against the physical stability. Gel formulation was made in 5 formulas with different HPMC concentrations, namely $1 \%$ (F1), $1.5 \%(\mathrm{~F} 2), 2 \%(\mathrm{~F} 3), 2.5 \%(\mathrm{~F} 4) \& 3 \%(\mathrm{~F} 5)$. Gel formulations are result, each evaluated for physical stability including, organoleptic, $\mathrm{pH}$, homogeneity, viscosity and spread ability. The organoleptis testing, $\mathrm{pH}$, homogeneity and viscosity were analyzed descriptively, while spread ability was analyzed statistically linear regression correlation, one-way ANOVA test. The results of the study showed that variations in the concentration of HPMC did not affect odor, shape, color, $\mathrm{pH}$ and homogeneity, but have affect viscosity and spread ability on each gel formulation, and all gel formulation are known to be stable during storage.
\end{abstract}

Keywords: Gel formulation, Physical stability, HPMC, Ethanol extract of Bundung Plant

\section{Introduction}

Indonesia is a country that has a wealth of useful plants and has been used traditionally as a medicinal ingredient based on hereditary experience for long ago. Until now, traditional medicine using natural ingredients is still often used and tends to increase from time to time. In addition to treatment, natural ingredients are also used as plant-based insecticides which are easly biodegradable so it does not pollute the environment and is relatively safe for humans. However, the use of plants as medicines and insecticides is only about $10 \%$ of the 20000-30000 species of plants that exist [1].

One of the plants that can be used as medicine is a Bundung plant (Actinoscripus Grossus), known as wild plants or weeds is a kind of puzzle grass that is often used by the community as a material for making woven craft. This plant generally grows in watery land or swamps. This plant is known to be widely used as an antimicrobial because it contains a class of secondary metabolite compounds namely flavonoids, tannins, saponins, phenolics, steroids and terpenoids and also efficacious as chelating or astringent, a good compound used to maintain skin health and beauty [2].

Now, the use of natural ngredients as a treatment is not only done by consumsing then but also by incorporating natural ingredients into topical products or cosmetic products. 
Pharmaceutical technology is developing rapidly in accordance with the desires and needs of th community for the appropriatedrug preparations. One of the dosage forms developed with pharmaceutical technology is gel. Gel preparations are widely used in the manufacture of hair make up, face makeup and skin care. The advantage of gel preparations is that they are not sticky and are also preparations that evaporate quickly and can deliver drugs well to the skin [3].

Gel preparations have a water content that is cool, shooting, moisturizing, easy to use, easy to penetrate to the skin, this providing effects such as healing [4]. Gel can be made with a variety of gelling agent, one of which is widely used in the pharmaceutical industry is Hydroxypropyl methylcellulose (HPMC) has good stability even after exposure to haet and in humid conditions will not experience significant changes observed in homogeneity, $\mathrm{pH}$, clarity, texture profile analysis and rheological properties of HPMC gels [5]. HPMC gel bases are often used in the production of cosmetics and drugs because they can produce gels that are clear, are easily soluble in water, and have low oxidation properties. In addition, HPMC produces a neutral gel, clear,

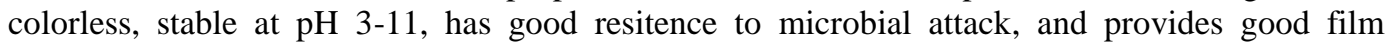
strength when it dries on the skin. The result of previous studies mention the base HPMC has a good rate of drug release, and wide spread power [6].

Based on this explanation, this study aims to make gel formulations and evaluations by knowing the effect of variations in concentration of HPMC as a gelling agent on the physical stability of gel formulations in ethanol extract Bundung plants (Actinuscirpus Grossus).

\section{Theoritical Basis}

\subsection{HPMC (Hydroxypropyl methylcellulose}

HPMC is a gelling agent that belongs to the semi-synthetic polymer group and is widely used as an excipient in topical dosage formulations. When compared with other gelling agent, HPMC produces clearer, neutral, colorless, tasteless liquids, produces gels with good viscosity in longterm, non-toxic, storage and does not irritate the skin. HPMC derived from methylcellulose in the form of granule of fibrous powder, white or creamy white, odorless and tasteless [7].

HPMC is used as an emulsifying agent, suspending agent, and as a stabilizing agent in topical preparations such as gels and ointments. HPMC dissolves very slowly and difficult, the recommended method is to provide hot water with a temperature of $80^{\circ} \mathrm{C}$ as much as $1 / 3$ or $2 / 3$ times the amount of HPMC because HPMC is easly soluble in hot water and spread evenly on the surface of hot water. Add organic solvents such as ethanol, propylene glycol or oilas solubility enhancers, then add the remaining water, causing the HPMC to become completely dissolved [7].

HPMC as a gelling agent in study showed that HPMC has the most optimal physical stability in gel preparations compared to carbopol. HPMC has good resistance to microbial attack and use of HPMC as a hydrophilic base also has advantages including producing good skin dispersion, cooling effect, not clogging skin pores, easy washing with water, and good drug release [8]. 


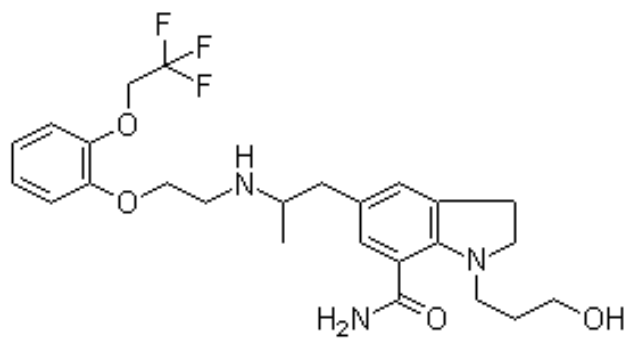

Fig. 1. Chemical structure of HPMC

\subsection{Gel}

Gel has better potential as a means of managing topical medications compared to oinments, karena gel tidak lengket, because gel not sticky, requires less energy for formulation, stable and has good aesthetics. Good gel can not be obtained by formulating several types of gelling agent, but the most important thing to note is the choice of gelling agent. In gel formulations, gelling agent component is acritical factor that can affect the physical properties of the gel produced [6].

Gel is generally a semisolid preparation which is clear, translucent and contains active substances, is a colloidal dispersion having strength caused by tissues that bind to each other in the dispersed phase [9]. Gel is widely used in medicinal, cosmetic and food products as well as in some industrial processes, in cosmetics namely as preparations for skin care, shampoo, fragrance preparations and toothpaste [10]. Gel preparations are more widely used because of cold feeling on the skin, easy to dry and can form a film layer so that it is easily washed. Gel is generally a semisolid saturated preparation, translucent and contains active substances [11].

Polymers commonly used to make pharmacetic gels include tragakan natural gums, pectin, carrageenan, agar, alginic acid, as well as synthetic and semi-synthetic synthesis materials such as methylcellulose, hydroxymethylcellulose, carboxymethylcellulose and carbopol wich are synthetic vinyl polymers with ionized carboxylic groups. Gel is made by a melting process, or a special procedure is required regarding the expanded nature of the gel [12]. Basic gels that are commonly used are hydrophobic gels and hydrophilic gels.

\subsubsection{Hydrophobic gel base}

Hydrophobic gel base generally consists of inorganic particles when added to the dispersing phase, there is very little interaction between this two phase. Unlike hydrophilic materials hydrophobic materials do not spontaneously spread, but must be stimulated by special procedures [9]. 


\subsubsection{Hydrophilic gel base}

hydrophilic gel base generally consists of large organic molecules and can be dissolved or combined with molecules from dispersing phase. The term hydrophilic means to like solvent. Generally, the attractiveness of hydrophilic materials is opposite of the absence of attractive attraction from hydrophobic materilas. Hydrophilic colloidal systems are usually to make and have greater stability [9]. Hydrophilic gel generally contains a component of developing ingredients, water, humectants and preservatives [13].

High water content in gel preparation can cause microbial contamination, which can effectively be avoided by adding preservatives. For stabilization efforts in terms of microbial in addition to the use if preservatives as in balm, especially for this base it is very suitable to use methyl a propyl paraben which are generally combined in form of preservative solution [13].

Advantages in preparation of gels in pharmaceutical world for the skin are as follows [14]:

\subsubsection{Long contact time}

Skin has barriers that are thick enough so it takes aa long time for active substance to penetrate the skin.

\subsubsection{High water content in gel}

A lot of water in gel will hydrate startum corneum so that changes in permeability of stratum corneum become more permeable to active substances which can increase the percentage of active substances.

\subsubsection{Risk of inflammation will be suppressed}

A lot of water content in gel can reduce the risk of further inflammation due to lipid in pores, because it is a bacterial food. Another effort needed is protection against evaporation, wich is to aavoid the probel of drying, so for storage is preferable to use a tube. 


\subsection{Bundung Plants (Actinuscirpus Grossus)}

1. Plant Classification

Kingdom
Subkingdom
Super Divisi
Divisi
Kelas
Sub Kelas
Ordo
Famili
Genus
Spesies

\author{
: Plantae (Tumbuhan) \\ : Tracheobionta (Tumbuhan berpembuluh) \\ : Spermatophyta (Menghasilkan biji) \\ : Magnoliophyta (Tumbuhan berbunga) \\ : Liliopsida (berkeping satu / monokotil) \\ : Commelinidae \\ : Cyperales \\ : Cyperaceae \\ : Actinoscirpus \\ : Actinocirpus grossus [15]
}

2. Plant Description

Bundung plants (Actinocirpus Gtossus) is a strong cluped plant, upright, multiplying with long stumps which culminate in a small tuber, sharp-stemmed stems with curved sides, smooth hair, $80-200 \mathrm{~cm}$ x 5-10 mm, leaves in a rosette, like lines, $50-80 \mathrm{~cm} \times 0,5-3 \mathrm{~cm}$, lower part forms a triangle so that it curves deeply, upper one curves shallowly with a flat and very pointy edge with sharp hair. Inflorescences, irregular, compound umbrellas, rough inflorescence axes, soft brush hairs, length is $4-17 \mathrm{~cm}$, the base there are some protective leaves that are not the same length, at least 2 of them are longer than flowering, length is $15-70 \mathrm{~cm}$, numerous spikelets, solitary, seated or stemmed, ovoid to elongated, spiky tipped, with many crammed flowers, 4-10 × 3,5-4 mm. Ovoid fruit upside down, with a tapered tip, smooth, brownish, one-third [16].

This grass thrives in paya-paya or places that are often inundated, pool edges, waterways, and swampy areas, especially in lowlands, up to a height of $850 \mathrm{~m} \mathrm{dpl}$. Also in irrigated fields, lebak fields and tidal fields [16].

Benefits of the stems are used to make strong webbing that last longer, but the price is cheap, for example is market mat and sack. This stem is first removed from one corner, then flanttened and flanttened with aa piece of bamboo, and dired in the sun. These sheets then condensed to turn white, before weaving them as needed [17]. 


\section{Research Methods}

\subsection{Tool}

Beker glass, Rotary evaporator, stirring rod, measuring glass, Water bath, analytic scales, maceration bottles, funnels, vaporizer cups, object glass, scatter power test plate, $\mathrm{pH}$ meter, viscometer.

\subsection{Ingredients}

Bundung plants (Actinoscirpus Grosssus), ethanol 70\%, HPMC, propylene glycol, propyl paraben, methyl paraben, orange essential oil, aquadest.

\subsection{Procedure}

\subsubsection{Extract Making}

Bundung plant extracts using maceration method. Extraction stages are as follows:

a) Added simplicia Bundung plant (Actinoscirpus Grossus) into percolator

b) Enter ethanol into percolator until soaking simplicia as high as $2-3 \mathrm{~cm}$

c) Close percolator, leave the marinade for 3 days while stirring occasionally

d) Extracted liquid from the percolator by filtering

e) Filtrate was then evaporated using a rotary evaporator with a thick extract. 


\subsubsection{Making Gel Preparations}

Table 1. Gel Formulation

\begin{tabular}{|c|c|c|c|c|c|c|c|}
\hline \multirow{2}{*}{ Bahan } & \multicolumn{7}{|l|}{ Formula $(\%)$} \\
\hline & I & & II & & III & IV & $\mathrm{V}$ \\
\hline $\begin{array}{l}\text { Bundung plant } \\
\text { extract }\end{array}$ & 1 & & 1 & & 1 & 1 & 1 \\
\hline HPMC & 1 & & 1,5 & & 2 & 2,5 & 3 \\
\hline Popilen glikol & 14 & & 14 & & 14 & 14 & 14 \\
\hline Metil paraben & 0,2 & & 0,2 & & 0,2 & 0,2 & 0,2 \\
\hline Propil paraben & 0,3 & & 0,3 & & 0,3 & 0,3 & 0,3 \\
\hline Orange essential oil & & $\begin{array}{c}3 \\
\text { drops }\end{array}$ & $\begin{array}{c}3 \\
\text { drops }\end{array}$ & $\begin{array}{c}3 \\
\text { drops }\end{array}$ & $\begin{array}{c}3 \\
\text { drops }\end{array}$ & $\begin{array}{r}3 \\
\text { drc } \\
\mathrm{s} \\
\end{array}$ & $\begin{array}{l}3 \\
\text { op } \\
\text { s } \\
\end{array}$ \\
\hline Aquadest ad & & $\begin{array}{c}100 \\
\mathrm{ml}\end{array}$ & $\begin{array}{c}100 \\
\mathrm{ml}\end{array}$ & $\begin{array}{c}100 \\
\mathrm{ml}\end{array}$ & $\begin{array}{c}100 \\
\mathrm{ml}\end{array}$ & $\begin{array}{r}10 \\
\mathrm{~m}\end{array}$ & $\begin{array}{l}00 \\
\mathrm{nl}\end{array}$ \\
\hline
\end{tabular}

Gel preparations are made using a hydrophilic base. Steps for making gel are as follows:

a) Weigh all the ingredients.

b) Heat aquadest to a boil then remove and add HPMC, expand for 15 minutes.

c) Dissolve methyl paraben and propyl paraben with propylene glycol little by little.

d) After HPMC expanded add the dissolved mixture of methyl paraben and propylene paraben.

e) Add extract of Bundung plant to mixture until its is homogeneous.

f) Add enough orange essential oil, stir until homogeneous and add distilled water ad $100 \mathrm{ml}$, stir until homogeneous.

\subsubsection{Evaluation of Gel Preparations}

a) Organolepric Evaluation

Organoleptic examination includes color, odor and homogeneity visually observed by applying $0,11 \mathrm{~g}$ of gel preparation to a transparant glass plate. If there are no coarse grains on plate, the gel tested is homogeneous.

b) $\mathrm{pH}$ Evaluation

$\mathrm{pH}$ evaluation of gel preparations using a $\mathrm{pH}$ meter. $0,5 \mathrm{~g}$ of the preparation to be examined and dissolved in $50 \mathrm{~mL}$ of water in a beaker. $\mathrm{pH}$ meter electrode is dipped in solution being examined, $\mathrm{pH}$ meter needle allowed to move until it shows a fixed position, $\mathrm{pH}$ indicated by the $\mathrm{pH}$ meter needle and then noted. 
c) Viscosity Evaluation

Determination of viscosity aims to determine the change in viscosity in each preparation formulation. As much as $100 \mathrm{~g}$ is taken into container, then the rotor is installed and ensured the rotor is submerged in the test preoaration. Stormer viscometer with rotor no. 4 is turned on and it is certain that under the rotor can rotate. Pointer of the viscometer is pointing to the number on the available viscosity scale.

\section{d) Scattering Evaluation}

$0,5 \mathrm{~g}$ of gel was carefully placed in center of the test scale in a soap opera scale and given a load on top 0f 0-1000 g for 3-5 minutes. Measure the diameter of distribution in a longitudinal, transverse and crossleft and right. Record diameter of the spreading gel.

\begin{tabular}{|c|}
\hline Planning and making proposals \\
\hline Preparation of tools \& materials \\
\hline Making simplicia \\
\hline Extract making \\
\hline Making gel with 5 formulations \\
\hline $\begin{array}{l}\text { Evaluation physical properties of gel: } \\
\begin{array}{ll}\text { 1. } & \text { Organoleptic } \\
\text { 2. } & \text { pH test } \\
\text { 3. } & \text { Homogeneity test } \\
\text { 4. } & \text { Viscosity test } \\
\text { 5. } & \text { Scattering test }\end{array}\end{array}$ \\
\hline
\end{tabular}

Fig 2. Research flow 


\section{Results And Discussion}

\subsection{Organoleptic test}

Table 2. First week organoleptic test results

\begin{tabular}{|c|c|c|c|c|c|}
\hline & \multicolumn{5}{|c|}{ Formula } \\
\hline & $\mathrm{F}_{1}$ & $\mathrm{~F}_{2}$ & $\mathrm{~F}_{3}$ & $\mathrm{~F}_{4}$ & $\mathrm{~F}_{5}$ \\
\hline Smell & $\begin{array}{l}\text { Typical } \\
\text { orange }\end{array}$ & $\begin{array}{l}\text { Typical } \\
\text { orange }\end{array}$ & $\begin{array}{l}\text { Typical } \\
\text { orange }\end{array}$ & $\begin{array}{l}\text { Typical } \\
\text { orange }\end{array}$ & $\begin{array}{l}\text { Typical } \\
\text { orange }\end{array}$ \\
\hline Shape & Rather thick & Thick & Thick & Thick & Thick \\
\hline Colour & $\begin{array}{l}\text { Brownish } \\
\text { yellow }\end{array}$ & $\begin{array}{l}\text { Brownish } \\
\text { yellow }\end{array}$ & $\begin{array}{l}\text { Light } \\
\text { yellow }\end{array}$ & $\begin{array}{l}\text { Light } \\
\text { yellow }\end{array}$ & $\begin{array}{l}\text { Light } \\
\text { yellow }\end{array}$ \\
\hline
\end{tabular}

Table 3. Organoleptic test results after 4 weeks of storage

\begin{tabular}{llllll} 
& \multicolumn{5}{c}{ Formula } \\
\cline { 2 - 6 } Smell & $\begin{array}{l}\mathrm{F}_{1} \\
\text { Typical } \\
\text { orange }\end{array}$ & $\begin{array}{l}\text { Typical } \\
\text { orange }\end{array}$ & $\begin{array}{l}\text { Typical } \\
\text { orange }\end{array}$ & $\begin{array}{l}\text { Typical } \\
\text { orange }\end{array}$ & $\begin{array}{l}\text { Typical } \\
\text { orange }\end{array}$ \\
\hline Shape & $\begin{array}{l}\text { Rather } \\
\text { thick }\end{array}$ & Thick & Thick & Thick & Thick \\
\hline \multirow{2}{*}{ Colour } & $\begin{array}{l}\text { Brownish } \\
\text { yellow }\end{array}$ & $\begin{array}{l}\text { Brownish } \\
\text { yellow }\end{array}$ & $\begin{array}{l}\text { Light } \\
\text { yellow }\end{array}$ & $\begin{array}{l}\text { Light } \\
\text { yellow }\end{array}$ & $\begin{array}{l}\text { Light } \\
\text { yellow }\end{array}$
\end{tabular}

Based on organoleptic test results it can be seen that gel preparations made have a brownish yellow color in formulations 1 and 2 and a light yellow color in formulations 3,4 and 5, for gel dosage forms obtained in formulation 1 rather thick and in other formulations is thick so differences in addition of HPMC concentrations affect the color and shape of gel formed, in journal [8] mentioned that greater amount of HPC gelling agent in each formula will give a thicker concentration of gel mass, and a slight color difference even though intensity of the color difference in each formula is not so significant. [6] also mentioned that the higher concentration of HPMC the thicker gel obtained.

Organoleptic test results after storage showed that preparation did not change from the first test, these results were supported by journal [18] which states there are no differences in results during storage. 


\section{2 pH Test}

Table 4. pH gel ethanol extract of Bundung plant test results

\begin{tabular}{ccc} 
& \multicolumn{2}{c}{$\mathrm{pH}$} \\
\cline { 2 - 3 } Formula & $1^{\text {st }}$ Week & $4^{\text {th }}$ Week \\
\hline I & 7,93 & 5 \\
\hline II & 7,97 & 5 \\
\hline III & 7,98 & 6 \\
\hline IV & 8,18 & 6 \\
\hline V & 8,19 & 6
\end{tabular}

$\mathrm{pH}$ testing on gel preparations aims to determine $\mathrm{pH}$ value of the resulting gel. From data table it can be seen that resulting of $\mathrm{pH}$ gel between 7,93-8,19 which exceeds the value of surrounding skins $\mathrm{pH}$ criteria 4,5-6,5 [19]. $\mathrm{pH}$ stability test results on all formulas show the results of a decrease in $\mathrm{pH}$ range to 5-6 which means $\mathrm{pH}$ of gel is unstable for 4 weeks after storage. The difference in $\mathrm{pH}$ produced can be caused by several factors, among these are environmental conditions of storage of gel preparations made such as light and humidity during the storage period after gel is made.

So it can be said that storage time is one of the factors that affect stability of gel $\mathrm{pH}$, the journal [20] said that there was an increase in $\mathrm{pH}$ extract geel preparations made and a decrease in $\mathrm{pH}$ in the blank preparations after storage even though $\mathrm{pH}$ change did not occur significantly. Other journals [6] also mentioned after storage occurs ups and downs of the $\mathrm{pH}$ value in preparation, but $\mathrm{pH}$ changes do not occur significantly. $\mathrm{pH}$ test results on gel preparations made show after storage the gel preparations made have a $\mathrm{pH}$ value that is included in normal $\mathrm{pH}$ value that is safe for skin. 


\subsection{Homogeneity Test}

Table 5. Homogeneity test of ethanol extract of Bundung plants

\begin{tabular}{cll} 
& \multicolumn{2}{c}{ Homogeneity } \\
\cline { 2 - 3 } Formula & $1^{\text {st }}$ Week & $4^{\text {th }}$ Week \\
\hline I & Homogen & Homogen \\
\hline II & Homogen & Homogen \\
\hline III & Homogen & Homogen \\
\hline IV & Homogen & Homogen \\
\hline V & Homogen & Homogen
\end{tabular}

Homogeneity test is intended to determine the presence or absence of particles that are not listed in gel preparation. Homogeneity test results of bund ethanol extract plants in the table shows that all gel preparations are made homogeneous. Gel is said to be homogeneous if the color is even and there are no lumps or separations [9]. According to the journal [20] gel is said to be homogeneous if it will not sshow any coarse grains when preparation applied to transparent glass. So it can be concluded that gel preparations have been made have a homogeneous arrangement [21].

Gel sstability test results on all formulations showed unchanged results which meaning that gel was stable for 4 week of storage after gel was made.

\subsection{Viscosity Test}

Table 6. Viscosity test results of ethanol extract of Bundung plant

\begin{tabular}{ccccc} 
& \multicolumn{4}{c}{ Viskositas (mPa.s) } \\
\cline { 2 - 5 } Formula & \multicolumn{2}{c}{ Pengukuran I } & \multicolumn{2}{c}{ Pengukuran II } \\
\cline { 2 - 5 } & $30 \mathrm{ppm}$ & $60 \mathrm{ppm}$ & $30 \mathrm{ppm}$ & $60 \mathrm{ppm}$ \\
\hline I & 1360 & 2620 & 2820 & 1990 \\
\hline II & 2720 & 5570 & 3100 & 2080 \\
\hline III & 5550 & 9030 & 5560 & 4670 \\
\hline IV & 8140 & 9450 & 11200 & 8560 \\
\hline V & 8350 & 10420 & 11339 & 9890
\end{tabular}




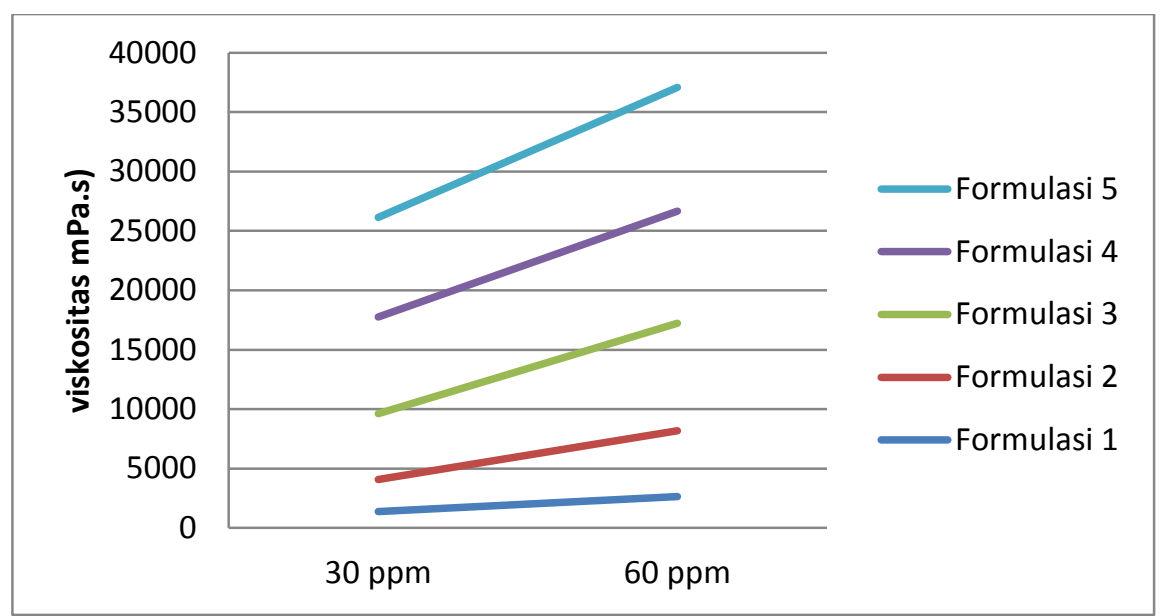

Fig 3. Viscosity of gel preparation before storage

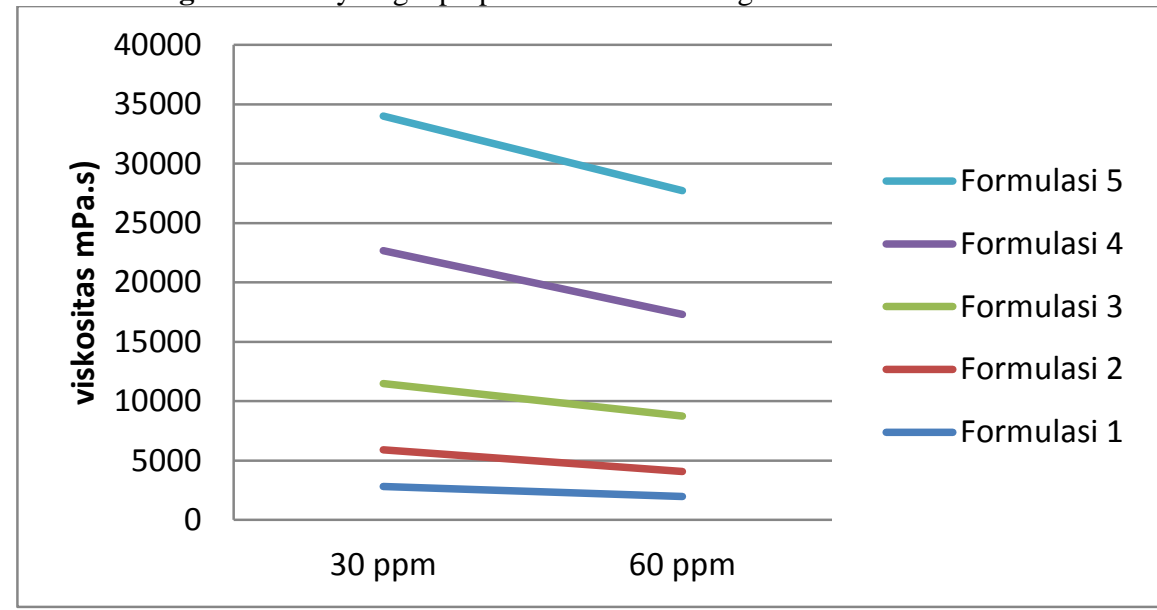

Fig 4. Viscosity of gel preparation after storage

Viscosity testing aims to determine viscosity value of a substance. Based on data in viscosity measurement results table shows that the greater HPMC concentration used the greater viscosity value obtained. This is because HPMC is a cellulose-derived polymer, which in the event of dispersion polymer molecules will enter the cavity formed by wter molecules, so hydrogen bonds occur between hydroxyl groups of polymer with water molecules. Hydrogen bond plays a role in hydration in swelling process, so higher concentration of HPMC, more hydroxyl groups that bind so higher the viscosity too [6]. Range of viscosity value of gel preparations between 2000-4000 cP [22]. Based on data obtained, it can be seen that formulations 1 and 2 have met the requirements of good gel viscosity because it is included into rang of viscosity values, while formullations 3,4 and 5 do not meet the requirements because they have a viscosity value that exceeds the range of viscosity values. 
Gel flow properties test results in table and graph show in first test all gel formulas have dilation flow because it shows an increase in iscosity value obtained by increasing rotation speed. But results of retesting after storage show that all gel formulas have pesudoplastic flow properties because value of viscosity decreases with increasing rotation speed. Gel is declared to hav pseudoplastic flow properties because it mtches the flow properties possessed by HPMC as a gelling agent [23].

Results of gel viscosity stability test showed a decrease in viscosity value in all formulas after storage, increasing the temperature of storage will affect the nature of HPMC which is causing polymer chain to break down so that the viscosity become thinner [23].

\subsection{Scattering Test}

Table 7. Spread test results of gel ethanol extract of bundung plant

\begin{tabular}{cccccc}
\multirow{2}{*}{\begin{tabular}{c} 
Load \\
\cline { 2 - 6 }
\end{tabular}} & $\mathrm{F}_{1}$ & $\mathrm{~F}_{2}$ & $\mathrm{~F}_{3}$ & $\mathrm{~F}_{4}$ & $\mathrm{~F}_{5}$ \\
\hline 52,48 & 5,42 & 4,6 & 4,57 & 4,02 & 4 \\
\hline 102,48 & 6,17 & 5,22 & 5,3 & 4,75 & 4,45 \\
\hline 152,48 & 6,52 & 5,72 & 5,72 & 5,17 & 4,67 \\
\hline 202,48 & 7,17 & 6,2 & 5,9 & 5,42 & 5 \\
\hline 252,48 & 7,57 & 6,45 & 6,35 & 5,87 & 5,2
\end{tabular}

Table 8. Spread test results of gel ethanol extract of bundung plant after 4 weeks of storage

\begin{tabular}{cccccc}
\multirow{2}{*}{\begin{tabular}{c} 
Soad \\
\cline { 2 - 6 }
\end{tabular}} & $\mathrm{F}_{1}$ & $\mathrm{~F}_{2}$ & $\mathrm{~F}_{3}$ & $\mathrm{~F}_{4}$ & $\mathrm{~F}_{5}$ \\
\hline 52,48 & 6 & 4,42 & 3,45 & 3 & 2,62 \\
\hline 102,48 & 6,97 & 5,15 & 3,92 & 3,45 & 2,92 \\
\hline 152,48 & 7,72 & 5,62 & 4,32 & 3,72 & 3,1 \\
\hline 202,48 & 8 & 5,85 & 4,6 & 4 & 3,37 \\
\hline 252,48 & 8,3 & 6,32 & 4,75 & 4,17 & 3,57
\end{tabular}

Results of gel spread test can be seen in the table. Spreadibility of suitable gel preparations is 5-7 $\mathrm{cm}$ or 5,54-6,08 $\mathrm{cm}$ based on SNI, while in the journal [8] it iss mentioned the spread of semisolid preparations suitable for topical use ranges from $3-5 \mathrm{~cm}$ in diameter. The spread test results obtained ranged from $4-7,57 \mathrm{~cm}$, these results indicated that the spreadability of all formulas meets 
the spreadability requirements so gel will spread well when applied. Based on the results of oneway ANOVA test statistics, significance value is obtained $0,004(<0,05)$ which means that there is a difference in the distribution of diameter of each formula group. Test results also showed that the higher concentration of HPMC used in gel preparation, the smaller spread diameter produced. This is because higher concentration of HPMC used, more resulting gel will be thicker which causes the ability to spread smaller. If the applied pressure is same for each formulation so more thicker the preparation and samller the ability to spread. Based on this, it can be concluded that increasing the concentration of HPMC can reduce the gel dispersion [23]. According to the journal [6] the higher concentration valu of gelling agent used, the lower spred power. According to other journal [8] the higher HPMC concentration, the xtent of spread decreases with increasing viscosity of gel, if the applied pressure is the same in every test formula, thicker preparations and the ability to spread smaller and smaller.

Results of stability test increase value in formulation 1 and decrease value in other formulations although the changes that occur are not significant and are still included in range of requirements. This results means that all gel formulations made can still maintain stability after 4 weeks of storage.

\section{Conclusion}

Based on research that has been done, it can be concluded that concentratioan of HPMC as gelling agent influences viscosity and dispersal power of gel ethanol extrac of Bundung plants. Gel formulation 2 containing 1,5\% HPMC has the best physical properties compared to others as seen from test results of dispersion and viscosity. Evaluation of $\mathrm{pH}$, viscosity and dispersibility of gel ethanol extract of Bundung plants fter storage showed a change in value but still included in range of requirements so that gel preparations made can be said to be stable.

\section{References}

[1] Prima Astuti H, Heti Nurcahyani. 2015. Ekstraksi Minyak Atsiri Daun Zodia (Evodia suaveolens) dengan Metode Maserasi dan Distilasi Air. Jurnal Bahan Alam Terbuka.

[2] Noval, N., Yuwindry. I, Syahrina. D. 2019. Pytochemical Screening And Antimicrobial Activity of Bundung Plants Extract by Dilution Methode. Jurnal Surya Medika (JSM). 5, 1(Aug.2019), 143-154.

[3] Sarah Pelen, Adeanne W, Gayatri C. 2016. Formulasi Sediaan Gel Anti Jerawat Minyak Atsiri Kulit Batang Kayu Manis (Cinnamomum burmanii) dan Uji Aktivitas Terhadap Bakteri Staphylooccus aureus. Jurnal Ilmiah Farmasi Vol 5 No 4.

[4] Septiani, S., N. Wathoni, dan S. R. Mita. 2011. Formulasi Sediaan Masker Gel Antioksidan dari Ekstrak Etanol Biji Melinjo (Gnetum gnemon Linn.). Jurnal Unpad. 1(1): 4-24.

[5] Dhawan, S., Medhi, B., \& Chopra, S., 2009, Formulation and Evaluation of Diltiazem Hydrochloride Gels for the Treatment of Anal Fissures, Scientia Pharmaceutica, 77, 465.

[6] Mirhansah A, Vebry A, Arsyik I. 2015. Formulasi dan Optimasi Basis Gel HPMC (Hidroxyl Propyl Methyl Cellulose) dengan Berbagai Variasi Konsentrasi. Vol 3. No 2. 
[7] Rowe, R.C. et Al. 2009. Handbook of Pharmaeuticaal Excipients. Edisi 6. The Pharmaceutical Press. London.

[8] Hanum Pramuji A, Mimiek Murrukmihadi. 2015. Pengaruh Variasi Kadar Gelling Agent HPMC Terhadap Sifat Fisik dan Aktivitas Antibakteri Sediaan Gel Ekstrak Etanolik Daun Kemangi (Ocimum basilicum L. forma citratum Back.). Majalah Farmasetik. Vol 11. No 2.

[9] Ansel. 1989. Pengantar Bentuk Sediaan Farmasi. Edisi Keempat. Jakarta: Universitas Indonesia Press.

[10] Herdiana. 2007. Formulasi Gel Uudesilenil Fenilalanin Dalam Aktivitas Sebagai Pencerah Kulit. Universitas Padjajaran.

[11] Lachman, L.,H, Lieberman, \& j.1., Kanih. 2007. Teori dan Praktek Industri Farmasi. Edisi III. UI Press. Jakarta. Hal.210-212.

[12] Lachman. 1994. Teoru dan Praktek Farmasi Industri III. Jakarta: UI Press.

[13] Voight. 1994. Buku Pengantar Teknologi Farmasi. Edisi V. Yogyakarta: Universitas Gajah Mada Press.

[14] Lieberman. 2005. Handbook of Sol-Gel Science and Technology 3 Applications of Sol Gel Technology. Springer Sciemce \& Business Media. Netherlands. Hal 271-273.

[15] Linnaeus filius. 1782. Supplementum Plantarum: Systematis Vegetabilium editionis Decimae Tertiae, Generum Plantarum editionis Sextae, et Specierum Plantarum editionis Secundae :104. Editum a Carolo a Linné. Brunsvigae [Braunschweig] :Impensis Orphanotrophei, 1781 [publ. Apr 1782.

[16] Kostermans, A.J.G.H., S. Wirjahardja, and R. J. Dekker. 1987. "The weeds: description, ecology and control": 260-1, inM. Soerjani, A.J.G.H. Kostermans, and G. Tjitrosoepomo, (eds.). Weeds of Rice in Indonesia. Jakarta :Balai Pustaka.

[17] Heyne, K. 1987. Tumbuhan Berguna Indonesia I: 352-3. Badan Litbang Kehutanan, Departemen Kehutanan. Jakarta. (versi berbahasa Belanda-1922-I: 294).

[18] Zakiah. 2015. Formulasi Gel Mengandung Lendir Bekicot (Achatina Fulica) serta Uji Aktivitas Antibakteri terhadap Propionibacterium Acnes. Prosiding Penelitian SPeSIA Unisba.

[19] Tranggono RI dan Latifah F. 2007. Buku Pegangan Ilmu Pengetahuan Kosmetik. PT. Gramedia Pustaka Utama. Jakarta.

[20] Ester Natalia, Awaluddin S., dan Djendakita P. 2012. Formulasi Gel Dari Ekstrak Rimpang Jahe Merah (Zingiber officinale roscoe).

[21] Ditjen POM. 1985. Formularium Kosmetika Indonesia. Jakarta: Depkes RI. Hal. 32-36.

[22] Garg, A., Aggarwal, D., Garg, S., dan Sigla, A.K. 2002. Spreading of Semisolid Formulation: An Update. Pharmaceutical Tecnology.

[23] Teti Idrawati, Fina Zissakina. 2011. Formulasi Gel Pengelupas Sel Kulit Mati yang Mengandung Sari Buah Nanas (Ananas comosus L) antara 17 sampai 78\%. Jurnal Ilmu Kefarmasian Indonesia. Vol 9. No2. 